\title{
Public Service by the Government of Papua Province in the Special Autonomy
}

\author{
Efraim Kambu \\ Cendrawasih University, Papua, Indonesia \\ e.kambu@yahoo.com
}

\begin{abstract}
Special Autonomy assigns its rights and obligations to local governments to regulate and manage their own affairs and interests of the society so that people increasingly can be served well. But in fact, public services provided is not maximized. This study used qualitative methods, data sources are divided into two types of data sources, namely primary and secondary data sources. The results of this study indicate that there is still lack of public services the Government of Papua Province visible from the weak aspects of responsiveness, which local governments less responsive to some of the problems in the field of education, economy and industry growth and physical development as well as non-physical. From the aspect of responsibility is also still found their weaknesses, which the Government of Papua Province is still not fully overcome the problems of corruption and poverty. Meanwhile, from the aspect of accountability, it is known that the performance of governance in Papua in providing public services are not running optimally, one reason is the lack of competence and capability of local government officials.
\end{abstract}

Keywords: Special autonomy, government, Papua, public service

\section{Introduction}

Papua or previously had the name Irian Jaya, before the year 2001 is a province that experienced a lot of pace compared to other provinces. Compared with abundant natural resources, the people of Papua is precisely in a state completely underdeveloped in comparison with the Indonesian community in another province. The issue of injustice, low welfare and law enforcement becomes then lead to disappointment that led to the conflict. So in the end, Papua also be one of the areas in Indonesia that has always plagued by conflict, particularly with respect to the conflict between the Free Papua Movement (OPM) with central government officials in Papua, the police and military. For OPM, Papua's independence is a matter that needs to be fought. The reason for being in the framework of the Unitary Republic of Indonesia (NKRI), the central government has never care about the fate of the people of Papua. As for the central government, Papua still must be part of the Unitary Republic of Indonesia, after previously losing East Timor in 1999 as a result of the referendum. In addressing the issues of underdevelopment and conflict in Papua, the Government subsequently approved Law No. 21 of 2001 concerning Special Autonomy for Papua Province. In other words, this law was born as a response to the central government of the overflow of the political resistance movement in Papua through demands for independence. However, the positive things from the Special Autonomy Law is this policy aims at encouraging Papua be on par with other provinces in Indonesia.

Special Autonomy for Papua not only provides an opportunity politically, especially with presence of Papuan People's Assembly (MRP), ${ }^{1}$ but also provides a great opportunity for growth and economic development in Papua. Economically presence of Special Autonomy for Papua has an impact on budget or the addition of special autonomy fund, the aim is for the development in Papua can run well. Policy of special autonomy for Papua, on the other hand not only provide the right but also the obligation for local governments, namely improving local government performance in public service. In fact, although the special autonomy has been running for 14 years, but local governments in Papua have not been able to realize the performance of public services. Whereas according Maisini (2015: 94) until now the Papuan people have not felt the so-called prosperous. Besides that the condition of the Papuan people in the fields of education, economy, culture and social politics is still very alarming when compared to other provinces in Indonesia. Likewise, based on the information report issued by the USAID (2014: 37) where the report

\footnotetext{
1 Papua People's Assembly (MRP) is an Institution in Papua Province, Indonesia the band consists of Indigenous Papuans What Being Equal with the parliament. In the Matter of Law No. 21 of 2001 on Special Autonomy for Papua Province, Chapter V, Form and Structure of Government, Explicitly Mentioned That the Main Pillars In The Governance of Papua Province Consists Of Three Parts. Three Components that is the Papuan Legislative Council (DPRP / DPRD), local government (governor Along These devices), and MRP.
} 
said that the challenge of assisting the implementation of public service governance in Papua Province is much more severe, particularly from the demand side. That though decentralization has been applied since 1999, the quality of performance of public services in the province of Papua has not shown any change for the better. Thus it can be said also that the successful institutionalization of political democracy has not been accompanied by adequate public service performance. Giving special autonomy rights, powers and obligations to the regions to set up and manage their own affairs and interests of local people, so that more people can be served well, but the reality is not like that. Due to the fulfillment of the interests and needs of the community it appears the Papuan community dissatisfaction against the government. From the exposure to these problems then this article takes the title of "Public Service by the Government of Papua Province in the Special Autonomy."

\section{Literature Review}

To conduct an analysis of the existing problems, some theories about public service raised. Public services according to Roth (1926: 1) is defined as a service provided to the public, both in general (such as in a museum) or specifically (like food restaurant). While Lewis and Gilman (2005: 22) defines public service as a public trust. Citizens expect public services can serve with honesty and management of income sources appropriately, and be accountable to the public. Public services are fair and accountable generate public confidence. It takes as a pillar of public service ethics and public trust as a basis to achieve good governance. Related to above view, that the public service is a public trust, the trust that is necessary to achieve presence of good service or quality. At least it should also be strengthened by the statement from Bharata (2004) who said that quality public services not only refers to the ministry alone, also emphasizes the process of conducting or distributing the service itself up into the hands of the public as consumers. To see the characteristics of good public services then it is worth considering the elements put forward by Kasmir (2006: 34), namely:

- The availability of a good employee.

- The availability of good infrastructure.

- Responsible to each customer from start to finish.

- Able to serve quickly and accurately.

- Ability to communicate.

- Provide a guarantee of confidentiality of each transaction.

- Has a good knowledge and ability.

- Try to understand the needs of customers.

- Able to give confidence to the customer.

In relation to the quality of public services provided by the bureaucracy in a democratic state at least according to Lenvine (1990: 188) must meet three indicators, namely responsiveness, responsibility, and accountability. Where Responsiveness is the responsiveness of service providers to the expectations, desires, aspirations and demands of service users. Responsibility is a measure that indicates how far the process of awarding public service was performed in accordance with the principles or provisions of the administration and the correct organization and has been assigned. Accountability is a measure that shows how much the process of service delivery in accordance with the interests of stakeholders and norms developed in the community. Apart from the theory or concept of public service, should also describe the theory and the concept of regional autonomy, and autonomy. Outlines the importance of both of these for public services by local governments in Papua, not in spite of their special autonomy granted. Regional autonomy according to Nurcholish (2007: 30) is the right of people living in an area to organize, manage, control and develop its own affairs with respect to applicable legislation. Things are not much different also expressed by the Widjaja (2001: 21-22), where he says autonomy is the government affairs transferred to the local government of an operational nature in the context of the system of government bureaucracy. In relation between regional autonomy imposed specifically in Papua, then according Sumule (2003: 49) that the special autonomy must be interpreted as freedom for the people of Papua to organize and take care of themselves, at the same time also means the freedom to selfgoverning and manage the utilization of natural resources in Papua for the welfare of the people of Papua. It is no less important in this particular autonomy is the freedom to determine the development strategy of social, cultural, economic and political accordance with the characteristics and peculiarities of human resources as well as natural conditions and culture of Papua. 


\section{Methodology}

This study uses a qualitative method. The data source is divided into two types of data sources, namely primary and secondary data sources. Primary data is data obtained directly through interviews and observations in the field. Secondary data were obtained through documentation relevant to this study, the literature on public services by the Government of Papua Province. The informants were interviewed in this study are: Frans Rumbrawer, Lecturer in Anthropology Studies Program, University of Cenderawasih; M. Rumbiak, Padjadjaran University Graduate Students from Papua. Observations carried out on various activities that made the object of research, namely in the form of public service activities of the Government of Papua Province. While the documentation of the analysis carried out on various documents related to the public service of the Government of Papua Province. Furthermore, the process of collecting data in this study tailored to the type of research. The data collected in this study, namely in the form of words, actions, documents, situations, and events that can be observed. Test the validity of the data in this study is done through triangulation, which is a technique of testing the validity of data is done by checking correctness of the data obtained by researchers in other parties who can be trusted. To maintain the validity of the data or research, efforts are based on the principles of triangulation. In this study, triangulation is done on the data sources, and use various supporting references, to prove the data that has been found in research, such as: recording, photographs or other documents that support.

\section{Analysis}

In order public services can achieve the desired goals, it needs to be supported by relevant elements, which is a supporting factor from the service process. The ineffectiveness of the factors to support public services will be able to inhibit the service itself. In Papua, an effort to provide better public services had also been a long time to implement, especially when Papua was granted special autonomy status. But the success or failure of these efforts need to be further analyzed with the theory, and to analyze the researchers used the theory of public services proposed Lenvine (1990: 188), where the quality of public services provided by the bureaucracy in a democratic state must meet three indicators, namely responsiveness, responsibility, and accountability.

Responsiveness: Aspects of responsiveness in the public service performed by the government, is related to the responsiveness of the government as a service provider to the expectations, desires, aspirations and demands of the service users, ie the public. Also associated with the the implementation of special autonomy, the government of Papua in aspects of responsiveness required to quickly understand what the public demands, and strive to meet them. Governments are encouraged to not procrastinate time, extending lines of service, or the importance of the procedure but ignoring the substance. With it then public services can be said to be good if the government is considered to have a high responsiveness to demands, problems, concerns and aspirations of the people. Associated with the demands, hopes, wishes and aspirations of the Papuan people, at least there are some things that have been identified, some of them:

- Regarding the increase in economic growth

- The improvement of welfare, which among others also includes the improvement of education and health

- Demands to the problem of housing construction and clean water.

- Development of physical and non-physical, such as infrastructure and transport.

(Source: from various sources, 2016) ${ }^{2}$

The emergence of the demands and aspirations of the people of Papua are things need to be considered by the provincial government, in view of the provision of special autonomy for Papua based on a desire or goal to make advanced Papua province and the same as other provinces. Papua Special Autonomy has provided an opportunity to significantly growing, but on the other hand needs to be the responsibility from local governments to implement good public services. Where one of them, local governments must respond to the demands and aspirations of the people. The emergence of the demands and aspirations of the people of Papua are things that need to be considered by the provincial government, considering the provision of special autonomy for Papua based on the objective to bring Papua province on par with other provinces. Papua Special Autonomy has provided an opportunity to significantly growing, but on the

Http://Www.Merdeka.Com/Uang/6-Tuntutan-Ekonomi-Rakyat-Papua-Ke-Pemerintah-Termasuk-Freeport.Html Http://Www.Merdeka.Com/Uang/6-Tuntutan-Ekonomi-Rakyat-Papua-Ke-Pemerintah-Termasuk-Freeport.Html
Http://Www.Dpd.Go.Id/Artikel-Tahun-Kesembilan-Otonomi-Khusus-Papua-Belum-Berhasil [Accessed February 17, 2016]. 
other hand need the accountability from local governments to implement good public services. Which one of them, local governments must respond to the demands and aspirations of the people.

In analyzing aspects of Papua Provincial Government responsiveness to demands, grievances or aspirations of its people, then the analysis is performed on data associated with the various demands and aspirations. To analyze the demands of economic growth, then the visible aspect is the growth of the banking and investment, trade, agriculture, and industry. From the banking and investment growth data, it is known that the position of rupiah deposits and foreign currency commercial banks in the province of Papua in 2014 was the lowest compared to previous years (2010-2013). Where rupiah deposits and foreign currency commercial banks, in 2014 only Rp. 2 billion, far different from the year 2013 which amounted to Rp. 29 billion and in 2012 which amounted to Rp. 26 bilion, or in 2010 the number is still far greater, namely Rp. 20 billion. Not only that, the number of cooperative units in the province of Papua in 2014 is much lower than in 2012 and 2013. In 2014 the number of cooperative units amounted to 2.420, the number is smaller than the year 2013, which amounted to 2.816, and in 2012 amounted to 2.580 . Although the number of cooperative units is reduced but this can be offset by the increasing number of investment companies in the domestic and foreign, are respectively 108 and 78 (previous year, ie 2013 by 103 and 75) (Source: BPS Papua Province, 2015). From the aspect of trade, though there were no comparative data, but the province of Papua have had a market share of exports to some countries for some agricultural commodities and industrial results, such as the United States, China and some other countries (Source: BPS Papua Province, 2015)

As for agriculture, which the assessment is the growth from the rice crop production, horticulture, vegetables and fruits. For the production of rice plants is increasing every year, where in 2014 the productivity of rice plants was amounted to 43.08 , while the production in 2013 amounted to only 41.30 . Although the productivity of rice plants increased, but the productivity of horticultural crops is precisely decreased, for example, productivity of medicinal plants in 2014 amounted to only 64.527, far less than the productivity in 2013 amounted to 421.968 . Also the case with the productivity of vegetables and fruits that come down, wherein each reaches only 21.939 and 8.525. Whereas in the previous year (2013) the productivity of vegetables amounted to 42.666 and 34.223 fruit trees of (Source: BPS Papua Province, 2015). Likewise in the industrial sector has not increased. As stated by the Minister of Industry, that the contribution of Papua to value added sector of national non-oil industry is still relatively small, which is 2.78\%. More minister reveals underdeveloped industrial infrastructure supporting the cause of the spread and equity industry is relatively slow. ${ }^{3}$ From the data above, efforts to promote economic growth is still not completely worked well. Public service performed by Papua Provincial Government has not done optimally, because there are still shortcomings in the regulation of rupiah deposits and foreign currency at commercial banks, decreased number of cooperative units and the decline of agricultural production plants, as well as the slow pace of industrial growth. In providing good service to the community, the Government of Papua Province can actually maximize efforts to resolve the issues above. As for example in the field of agriculture, the Papua Provincial Agriculture Office should be able to maximize outreach activities and provision of agricultural plant seeds so that agricultural production can be increased.

Demands improvements in welfare, which among others also includes the improvement of education and health. That from the Central Statistics Agency (BPS) Papua (2015), the level of poverty in the province of Papua in 2015, amounting to 28.17, a slight increase compared to 2014, amounting to 27.80. In the education sector, there is still a problem where the number of high school graduates (SMA) / equivalent is still smaller from the number of graduates of Elementary School (SD) / equivalent. For a number of high school graduates is at 30.04 while for primary school graduates is 75.86 . The low educational level repairs, servicing shows educational system run by the government of Papua Province has not been effectively implemented. For the aspects of health care, conditions are still better than education, because every year the number of Papua Province Morbidity tends to fall. For example in 2014 Morbidity figure amounted to only 8.67, this figure is far from the year 2013 which reached 18.97 (Source: BPS Papua Province, 2015). The fall in these rates can be used to measure the level of public health in the province of Papua. While in terms of response to the demands of housing construction and clean water, can be said to be a decline in provincial government services in providing adequate housing and have enough clean water. In the provision of housing, decent housing indicators in 2014 with the kind of ground floor not

\footnotetext{
3 Http://Financeroll.Co.Id/News/Saleh-Husin-Target-40-Persen-Industri-Diluar-Jawa-Infrastruktur-Pendukung-Jadi-Kendalanya/
} [Accessed February 19, 2016] 
only at 77.95, is smaller compared to the year 2013, which amounted to 79.48 (Source: BPS Papua Province, 2015).

Against a response to the demands of the development of physical and non-physical, such as infrastructure and transport. That the development of physical and non-physical in Papua has been slow. Although the financial resources available to the provincial governments, districts and municipalities for planning and infrastructure investment has increased dramatically in the last decade. Papua provincial government received transfers from Jakarta Rp 4.8 billion in 2008 (up from Rp 0.4 billion in 2000), while the district / city government received Rp 17.0 bilion (up from Rp 1.2 bilion a year 2000). In the total amount for 2008 is still not added one to two trillion to local revenue. However, useful infrastructure services provided to the population of Papua is only slightly increased. ${ }^{4}$ There are still problems in terms of improving the economy, welfare and development may be an indication that the Papua Provincial Government has not fully respond to the demands, aspirations and desires of the community. The slow pace of a response or not the government in responding to the demands of society can have an impact on disappointment with attitude and performance of the government. Whereas for the public, the slow response of the government to make the public more difficult to develop.

Responsibility: The second indicator that also need to be considered in the public service by bureaucracy / government is the responsibility, where it is associated with a measure that indicates how far the process of public service provision is carried out in accordance with the principles of proper administration and organization. Regardless to correct standard of rules for the administration and organization, then there will be a wide variety of potential irregularities in public service delivery, such as corruption and the slow pace of public services. The problems of corruption and poverty close to audience feedback on Papua, this condition can occur in the absence of administrative provisions and the correct organization in providing public services. Director General (DG) Autonomous Region, the Ministry of Internal Affairs of Indonesia, namely Djohermansyah Djohan, revealed that the implementation of good public services in Papua related to post-special autonomy (Otsus), but unfortunately the policy implementation of special autonomy in Papua cannot be said to be successful. The one that caused it, he said, are the patterns and working mechanism has not been awakened synergistically. ${ }^{5}$ The problem of working mechanism is also a matter highlighted by the informants of this study, in which both the informant stated that the lack of working mechanism of employees due to the pattern of recruitment is still based on the relationship of ethnicity and kinship, also the case in staffing that is not based on the principle of the right man in the right place. ${ }^{6}$ Supposedly pattern of recruitment and staff by level of education and competence of employees, if the pattern of kinship or nepotism still characterize the process of placement and recruitment of employees, it can affect the commitment to create good governance.

Public service in Papua with the color of red, this assessment together with an assessment of all 12 other provinces. By getting the red category means the public service in the province of Papua is relatively low. Rate lack of public services in Papua, one of which is inseparable from the poor standards of the organization in providing services. The Ombudsman assesses the poor standards of the organization of several things, including: the availability of the vision and mission of the service, as well as the availability of information on standards of public service for the community. ${ }^{7}$ With the reference of the votes at least can be identified, what is the cause of public service in Papua gets red values, one of which is caused by the lack of clarity of size or standard of rules for the administration and organization in providing public services. Clarity on the size or standard of rules for the administration and organization are important, these standards should be set out clearly in the vision and mission of the Government of Papua Province.

Besides, size or standard of also should be known by the public, hence the availability of clear information for the public on standard of public services should be provided by the Government of Papua Province. Nonetheless, that does not mean there is no effort from the local government to seek to tackle the problem. Regional Government of Papua Province has actually also been carrying out government

${ }^{4} \mathrm{Http} / / /$ Siteresources.Worldbank.Org/Intindonesia/Resources/Publication/280016-1235115695188/5847179-

1263873728984/Exsum.Bh.Pdf [Accessed February 19, 2016]

${ }^{5}$ Http://Www.Balairungpress.Com/2012/11/Menumbuhkan-Optimisme-Lewat-Pelayanan-Publik-Di-Papua/ [Accessed February $17,2016]$.

${ }^{6}$ The interview with Frans Rumbrawer, Lecturer in Anthropology Studies Program, University of Cenderawasih, and M. Rumbaik, Graduate Student, University of Padjadjaran, from Papua. [Interview conducted on March 28, 2016].

${ }^{7}$ Http://Www.Jurnalasia.Com/2015/12/18/Standar-Pelayanan-Publik-Di-13-Provinsi-Rendah/ [Accessed February 17, 2016]. 
regulation and Regulation of the Minister of Internal Affairs. Some Performance Unit (SKPD) of the Government of Papua Province has made minimum service standards. However, the problem that arises is that the Government of Papua Province has not had guidelines for public service standards. As a result, many SKPD improvise their own in determining the standard public services. In addition, many SKPD are still feel confused in determining the standard public services. Therefore, it is very urgent for the Government of Papua Province to promptly develop guidelines for standards of public service that can be used by SKPD overall and sustainable reconstitute the minimum service standards. Standards of public service that is owned by the government sub-organizations can accelerate the process of public service, and this is also in accordance with the need to create good governance.

Accountability: In the public service performed by the bureaucracy, accountability related to a measure that indicates how much the service delivery process in accordance with the interests of stakeholders and norms developed in the community. In connection with the special autonomy granted to Papua, accountability in the public service need to pay attention to the recognition and fulfillment of the basic rights of indigenous Papuans. In addition, public services within the framework of special autonomy must also consider the empowerment of the people of Papua strategically and fundamentally. The importance of paying attention and meets, as well as empowering the basic rights of indigenous Papuans in providing public services, because of the special autonomy gives authority and responsibility to the provincial government to take care of public interests at its own initiative based on the aspirations and fundamental rights of the Papuan people. Granting of Special Autonomy for Papua Province is intended to bring about justice, uphold the rule of law, respect for human rights, accelerating economic development, improving the welfare and progress of the people of Papua, in the framework of equality and balance with the progress of other provinces. Special autonomy through Law No. 21 of 2001 put the Papuan people and the people of Papua in general as a major subject. The existence of the Provincial Government of Papua and the unit below, are directed to provide the best services and empower people.

But in hopes of increasing public services for indigenous Papuans, but until now the performance of Papua local government in providing public services are not running optimally. Although they are made several breakthroughs to spur the progress of Papua, but still many people perceive Papua is still underdeveloped. The more backward in terms of public service that ends an impact on the living standards of welfare. As Maisini (2015) in his research see that the government pays little attention to the potential and capacity of local communities as agents of development. Condition that occurs precisely the people of Papua is still poor, the development was considered failed, bureaucracy failing to create a ministry of basic rights and good performance for the public. Likewise with Wanimbo (2015) that in the conclusions of his research revealed that special autonomy is set forth in Law No. 21, 2001 has not succeeded in giving a guarantee for the improvement of public welfare, prosperity and recognition of the basic rights of indigenous people of Papua.

Related to the lack of public services provided by the Provincial Government of Papua, the government should be able to reflect on some of the root causes of conflict in Papua, which is caused by the unfairness of the economy, such as the exploitation of natural resources and the participation of indigenous peoples is lacking, cultural domination and human resources development bias, marginalization and discrimination, as well as development failure. To solve the root of the problem, no doubt it is also necessary of qualified government officials. If the Government of Papua Province has qualified human resources, it will be able to assist government programs in empowerment and fulfillment of the rights of the Papuan people. Related to the above, an informant in this study revealed that the "quality of personnel in the Papua provincial government does not live up to expectations, many employees do not understand and explore the purpose of special autonomy. The issue of the lack of quality of human resources is also due to the recruitment system is still based on factors of tribal or kinship, and is not based on competence."8 From the information given by the informant, it is known that one of the causes of unfulfilled rights of indigenous Papuans is due to lack of competence and capability of local government officials. This condition is a problem that must be addressed by the Government of Papua province, because the people of Papua should immediately get better public services so that their rights are met.

8 The interview with Frans Rumbrawer, Lecturer in Anthropology Studies Program, University of Cenderawasih. [Interview conducted on March 28, 2016]. 


\section{Conclusion}

Although the special autonomy has been running for 14 years, but local governments in Papua have not been able to realize good public service, until now the people of Papua have not felt the so-called prosperous, just and prosperous. Low public service of the Government of Papua Province seen from the weak aspects of Responsiveness, where the government is not responsive to some of the problems in the field of education, economy and industry growth, as well as the physical and non-physical development. From the aspect of responsibility is also still found their weaknesses, which the Government of Papua Province is still not fully overcome the problems of corruption and poverty, because the pattern and working mechanism has not been built synergistically. Low employee working mechanism caused by the pattern of recruitment which is still based on ethnicity and kinship relationships. While the last aspect, that is accountability, it is known that the performance of governance in Papua in providing public services are not running optimally. One cause of unfulfilled rights of indigenous Papuans is due to lack of competence and capability of local government officials. Therefore, the Papua provincial government needs to do some improvements in order to improve the quality of public services, one must be responsive to the demands of society, responsible for the mandate given by the people, and accountable.

\section{References}

Bharata, A. (2004). Dasar-dasar Pelayanan Prima. Jakarta : Elex Media. Komputindo.

Kasmir. (2006). Manajemen Perbankan. Jakarta : PT. Raja Grafindo Persada.

Lenvine, C. H. (1990). Public Administration: Chalenges, Choices, Consequences. Illionis: Scott Foreman.

Lewis, C. W. \& Gilman, S. C. (2005). The Ethics Challenge in Public Service: A Problem-Solving Guide. Market Street. San Fransisco: Jossey-Bass.

Maisini, A. (2015). Pelayanan Publik oleh Pemerintah Daerah dalam Penyelenggaraan Otonomi Khusus Papua. Jurnal Lex Administratum, 3(4), Juni 2015.

Nurcholis, H. (2007). Teori dan Praktik Pemerintahan Dan Otonomi Daerah. Jakarta: PT. Grasindo.

Roth, G. J. (1926). The Privat Provision of Public Service in Developing Country. Washington DC: Oxford University Press.

Sumule, A. (2003). Mencari Jalan Tengah; Otonomi Khusus Provinsi Papua. Jakarta: PT. Gramedia Pustaka Utama.

USAID. (2014). Modul Tata Kelola Pelayanan Publik Berbasis Standar. Jakarta: USAID.

Wanimbo, D. (2015). Implementasi Otonomi Khusus dalam Proses Pelayanan Publik (Studi Tentang Proses Pelayanan Bidang Pendidikan Dan Kesehatan Kabupaten Lanny Jaya Propinsi Papua). Jurnal Politico, 2(6).

Widjaja, H. A. W. (2001). Otonomi Daerah dan Daerah Otonom. Jakarta: PT. RajaGrafindo. 